\title{
実践研究
}

\section{病院内教育における小児がんや慢性疾患の児童生徒に対する 「体験的な活動を伴う学習」に関する研究}

\author{
土屋 忠 之*・武 田 鉄 郎**
}

体験的な活動を伴う学習（以下、体験的な学習）は、自然や社会や人々とのかかわりの中 で行われ、社会性や生きる力を育む重要な役割がある。治療や病状のため、さまざまな制限 のある小児がんや慢性疾患の児童生徒は、入院中、日常的な体験がそしくなるため、自然や 社会体験を補う必要がある。そこで、病院内にて教育を行っている学校や学級の体験的な学 習を調査し、考察を行った。調査結果から、病院内では種々の制限のため、自然や社会の体 験的な活動を健常児と同様に行うのは難しいことが明らかになった。一方、制限への対策と して、学校が病院の協力を得て「内容・方法・場所の工夫」治療・処置の調整」、病院や外 部の「施設や人材の活用」等を行うことにより、病院内教育にてさまざまな体験的な学習が できることや、活動の必要性が示唆された。また、学校が病院と「病状や配慮事項」「活動 内容」等の情報を共有・調整し、協力や相互理解により、活動できるようになることも示唆 された。

キー・ワード：病弱教育 自然・社会体験 教育と医療の連携 小児がん 慢性疾患

\section{I . 問題と目的}

体験的な活動を伴う学習 (以下、体験的な学習) は、 自然や社会や人々とのかかわりの中で展開され、社会 性や共に生きる力を育むうえで重要である(文部科学 省, 2002)。このようなことが望まれるのは、健康な子 どもばかりではない。特に慢性疾患児は、より「生き る力」を身につけられるような支援が必要であり（川 崎 - 尾川 - 山崎 - 池田 - 園田 - 郷間, 2006)、川崎 - 牛 尾・石田・尾瀬・郷間（2008）は、慢性疾患児の自然 体験は疾患の回復のみならず、生活や自分自身に幅を もたせ、豊かな人間性を養うと述べている。

そのため、慢性疾患児の経験で不足している部分に ついては、可能な限り教育活動の中で取り上げること が重要であり（横田・小野, 1995)、病状に配慮しなが ら、直接経験ができる機会を多くするように努めるこ とが大切となる (文部省, 1996)。特別支援学校 (病弱) の教職員がおもな構成会員である全国病弱虚弱教育 研究連盟の機関紙「病弱虚弱教育」の 44 号 (2004)〜 49 号（2009）には、体験的な学習の多くの実践報告が

\footnotetext{
*東京都立墨東特別支援学校
}

$* *$ 和歌山大学教育学部
ある。また、平成 21 年 3 月告示の特別支援学校小学 部・中学部学習指導要領には、特別支援学校 (病弱) にて体験的な活動を伴う内容の指導を行うにあたつて は、児童の病気の状態や学習環境に応じて効果的な 学習活動が展開できるようにすることが明示されて いる。

ところで、病院内での教育は、特別支援学校および 小学校・中学校の病弱・身体虚弱特別支援学級で行わ れている。対象児童生徒は、治療や病状のため種々の 制限のある小児がん・白血病等の悪性新生物や、腎臟 疾患・心臟疾患等の慢性疾患（以下、小児がんや慢性 疾患）が多く、体験的な学習を行ううえでは制限への 対策が必要である。制限が著しく、病室での授業が必 要な場合は、教材・教具を工夫する必要がある（文部 省, 1996)。このような状況の中、各学校・学級（以下、 学校）では、各病院・病棟（以下、病院）の協力を得 て病気による種々の制限への対策を行い、体験的な学 習を実施していると考えられるが、その実態は明らか になっていない。そこで、病院内教育における自然や 社会にかかわる体験的な学習の実施状況を調査し、制 限となる要因と各学校が行っている対策について明ら かにする。 


\section{II. 方 法}

\section{1. 調査対象}

特別支援学校 (小学部・中学部) または小学校・中 学校の病弱・身体虚弱特別支援学級に所属しており、 入院している小児がんや慢性疾患の児童生徒へ教育を 行った経験のある教員を対象として調査を行った。教 員の所属校は、子ども病院・大学病院・がんセンター にて病弱教育を行っており、小児がんや慢性疾患の児 童生徒が数多く在籍している学校とした。

\section{2. 調査方法}

病院に併設または病院内に設置された特別支援学校 （分校、分教室を含む） 15 校、病院へ訪問教育を行っ ている特別支援学校 9 校、小・中学校の病弱 - 身体虚 弱特別支援学級 36 学級、計 60 校・学級（以下、校） へ平成 16 年 9 月に質問紙を送付し調査を行った。回 答は、北海道地区 1 校、東北地区 2 校、関東甲信越地 区校 25 校、近畿・東海・北陸地区 9 校、中国・四国 地区 4 校、九州地区 6 校、計 47 校からあり、回収率は $78.3 \%$ あったた。た、アンケート調査を行った学校 に出向き、インタビューによる補助調査を平成 $17 \sim 18$ 年に行った。

質問項目は、平成 11 年発行 (平成 16 年 3 月一部補 訂）の小学校および中学校学習指導要領解説を参考に して作成した。特に、理科編「理科の目標」、総則編 「総合的な学習の時間の学習活動を行うにあたっての 配慮事項」を参考に作成した。なお、「理科の目標」 は、小学校と中学校で大きく異なるため、小学校のも のを参考にした。作成した質問項目のおもなものを Table 1 に示した。

調査結果の処理は、記述統計によった。また、自由 記述の回答は、問題・課題の内容 1 件につき、 1 枚の カードに書き出し、次にそれらのカードを類似した項 目ごとに整理分類するカテゴリー分析により、病弱教 育を専門とする研究者と特別支援学校の教員の 2 名で 分類した。Table 2 Table 8 に、分類の項目と具体例 を示した。

\section{III. 結 果}

\section{1. 自然体験活動を行うための設備、実施場所}

（1）動物・昆虫・植物（以下、動植物等）を育 てるための設備：回答のあった 47 校のうち、「教材 園」が最も多く 2 割強の 11 校に設置されており、「観 察池・大型水槽」は 3 校、「飼育舎」は 2 校であった。

（2）動植物等の観察実験の場所：回答のあった 33 校のうち、「教室・校舎内のみ」が 5 割強の 18 校で
Table 1 おもな質問項目

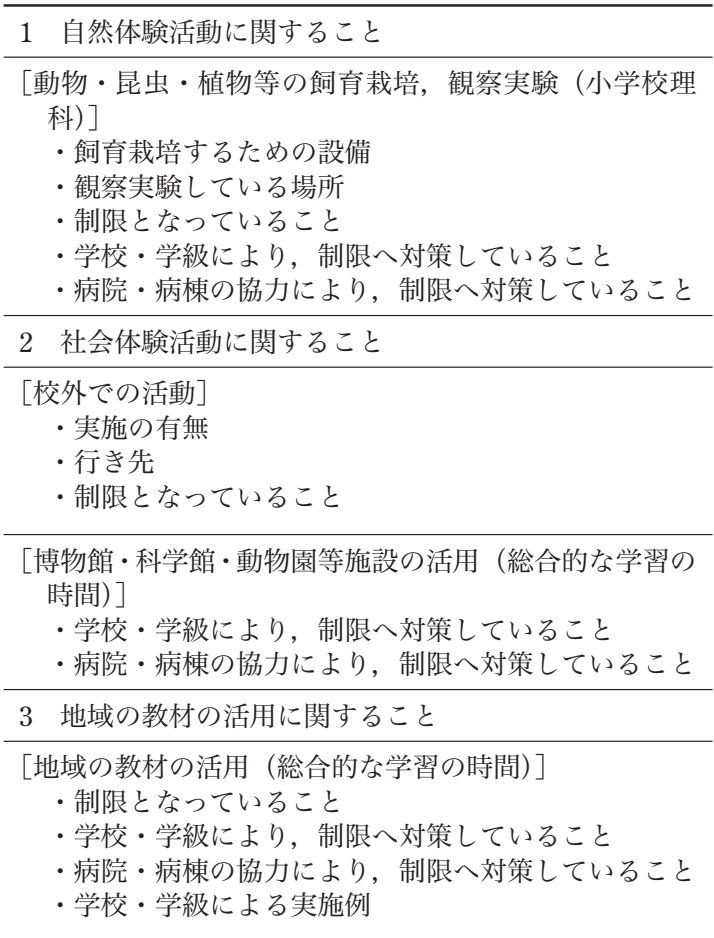

最も多かった。「教室・校舎内掞よびベッドサイド」 および「教室・校舎内およびその他の場所」が 3 校、 「ベッドサイドのみ」が 2 校であった。「行っていない」 という回答が、約 1 割の 5 校であった。

2. 自然体験活動を実施するうえでの制限となる要 因およびその対策

（1）動植物等の飼育栽培、観察実験を実施する うえで制限となる要因 (Table 2 参照)：自由記述の回 答を整理分類すると、「感染予防への配慮」(21 件) が 最も多く、次いで「病状による活動制限」(4 件) があ り、生活規制による配慮・制限が多かった。また、「飼 育栽培場所の問題」(3 件)、「児童生徒の個々の実態へ の配慮」（2 件）があった。

（2）動植物等の飼育栽培、観察実験等を実施す るうえでの対策 (Table 3 参照)：学校による対策およ び病院の協力による対策については、学校による「感 染予防のための内容・教材の工夫」(25 件) が最も多 く、学習内容・教材に関して多くの学校が対策を行っ ていた。また、「病状の連絡・調整」は、学校の依頼 により 7 件、病院の協力により 9 件、「活動内容の連 絡・調整」は学校の依頼により 6 件、病院の協力によ り 10 件行われており、病状や活動内容に関して学校 
病院内教育における小児がんや慢性疾患の児童生徒に対する「体験的な活動を伴う学習」に関する研究

Table 2 動物・昆虫・植物等の飼育栽培，観察実験を実施するうえでの制限となる要因

\begin{tabular}{|c|c|c|}
\hline 類 & 件 & 具 \\
\hline 感染予防への配慮 & 21 & $\begin{array}{l}\text { ・土や虫類に直接触れられない } \\
\text { •病院内の教室, ベッドサイドでは，動植物は持ち込めず，飼育，栽培は不可 } \\
\text { •病院の感染委員会に意見を求める必要がある }\end{array}$ \\
\hline 病状による活動制限 & 4 & $\begin{array}{l}\text { ・車椅子での活動のため制限がある } \\
\text { ・児童が入手したり, 継続した世話や観察をしたりできない }\end{array}$ \\
\hline 飼育栽培場所の問題 & 3 & $\begin{array}{l}\text { ・場所がない } \\
\text { ・屋上のため水やりの場所が遠い } \\
\text { ・室内での栽培のため, 育ちが悪い }\end{array}$ \\
\hline 児童生徒の個々の実態への配慮 & 2 & ・一人一人の病状が異なり, 許可や活動内容もそれぞれに対応する必要がある \\
\hline
\end{tabular}

Table 3 動物・昆虫・植物等の飼育栽培, 観察実験を実施するうえでの対策

\begin{tabular}{|c|c|c|}
\hline \multicolumn{3}{|r|}{ 学校・学級による対策 } \\
\hline 類 & 件 & 体 \\
\hline 感染予防のための教材・方法の工夫 & 25 & $\begin{array}{l}\text { •ゴム手袋，マスクを着用させ，ビニルパック等で密閉する等，動植物等に } \\
\text { 直接触れさせない } \\
\text { ・観察後の手洗い・うがいを実施 } \\
\text { ・木の実等は熱湯消毒して使用する } \\
\text { ・屋外の草花を写真, ビデオに撮つて見せる }\end{array}$ \\
\hline 病状の連絡・調整 & 7 & $\begin{array}{l}\text { •病院から触って良い児童, できない児童を伝えてもらう } \\
\text { •病院の連絡表等から病状，検査結果等の情報を得る }\end{array}$ \\
\hline 活動内容の連絡・調整 & 6 & $\begin{array}{l}\text { •事前に病院サイドに活動計画・内容を伝える } \\
\text { ・活動内容を管理区分に合わせて, 病院と相談する }\end{array}$ \\
\hline 病院へ飼育栽培場所の依頼 & 2 & •病院へ依頼して駐車場の一部に小さい栽培園を設置 \\
\hline \multicolumn{3}{|r|}{ 病院・病棟の協力による対策 } \\
\hline 類 & 件 & 具 \\
\hline 活動内容の連絡・調整 & 10 & $\begin{array}{l}\text { • 教材を見る等, 教室内に持ち込んで良いもの, 方法を相談 } \\
\text { ・動植物等の様子を知り，直接触れて良いかどうか判断する } \\
\text { ·児童の学習活動の予定を知る }\end{array}$ \\
\hline 病状の連絡・調整 & 9 & $\begin{array}{l}\text { •その日の児童生徒の病状, 注意事項等を学校へ伝える } \\
\text { ・治療の制限で, 直接さわれない手袋の使用を連絡 } \\
\text { • 年 } 2 \text { 回の連絡会の際に, 病状や配慮する事項を伝える }\end{array}$ \\
\hline 学校と飼育栽培場所の相談 & 2 & ・屋上ガーデンの一部の使用を相談 \\
\hline 治療・処置の調整 & 1 & ・学習内容により治療時間の変更をする \\
\hline
\end{tabular}

と病院が連絡・調整を行っていた。その他、学校によ る「病院へ栽培場所の依頼」( 2 件)、病院の協力によ

る「学校と飼育栽培場所の相談」( 2 件) が行われてお り、設備の問題に関して、学校が病院の協力を得て対 策をとっていた。

\section{3. 校外での活動の実施率、実施場所および制限と} なる要因

（1）校外での活動の実施率：校外での活動は、 回答のあった 45 校のうち、6 割弱の 25 校が実施して
いた。

（2）校外での活動の行き先：校外学習を実施し ていると回答した 19 校のうち、「博物館・科学館・動 物園等の施設（以下、博物館等施設）」が最も多く、6 割弱の 11 校であった。次いで、「公園等」が 7 校、「工 場等」 3 校、「デパート」2校、「畑」1校であった。

（3）校外での活動を実施するうえでの制限とな る要因 (Table 4 参照)：「病状による外出制限」(14 件）が多く、外出への活動制限があった。また、「学 
Table 4 校外での活動を実施するうえでの制限となる要因

\begin{tabular}{|c|c|c|}
\hline 類 & 件 & 体 \\
\hline 病状による外出制限 & 14 & $\begin{array}{l}\text { ・点滴等をつけているため難しい制限がある } \\
\text { ·免疫力が弱く感染に対する配慮 } \\
\text { ·病院から外出することは許可されていない }\end{array}$ \\
\hline 学校・学級の体制 & 4 & $\begin{array}{l}\text { ·教員数の不足 } \\
\text { ・予算の問題 }\end{array}$ \\
\hline 病院・病棟の体制 & 4 & $\begin{array}{l}\text { ・医師・看護師の付き添いが困難 } \\
\text { ・病棟が複数あつて, 調整も難しい }\end{array}$ \\
\hline 児童生徒の個々の実態への配慮 & 2 & $\begin{array}{l}\text { ・児童生徒の状況が多様で対応が難しい } \\
\text { ・外泊する児童生徒が増え, ニーズも減ってきている }\end{array}$ \\
\hline
\end{tabular}

Table 5 博物館・科学館・動物園等の施設を活用するうえでの対策

\begin{tabular}{|c|c|c|}
\hline \multicolumn{3}{|r|}{ 学校・学級による対策 } \\
\hline 類 & 件 & 具 \\
\hline 活動内容・場所の工夫 & 8 & $\begin{array}{l}\text { ・参加できない児童生徒の実習方法を学芸員と相談する } \\
\text { ・博物館員が資料等を運び, 学校を会場として出張講座を開く } \\
\text { ・図書館から図書を長期に借用する } \\
\text { ・情報機器の活用 }\end{array}$ \\
\hline 活動内容の連絡・調整 & 2 & $\begin{array}{l}\text { ・活動日を事前に連絡する } \\
\text { ・外出させる時は, 必ず病院へ連絡し, 相談する }\end{array}$ \\
\hline 病院へ付き添いを依頼 & 2 & •医師の付き添いを依頼する \\
\hline 病院へ治療・処置の相談 & 1 & •医師が治療予定を活動日に合わせて，ずらしてくれるか相談 \\
\hline 病院との相互理解 & 1 & ・活動の必要性について病院の理解を得る \\
\hline \multicolumn{3}{|r|}{ 病院・病棟の協力による対策 } \\
\hline 類 & 件 & 具 \\
\hline 活動内容の連絡・調整 & 3 & $\begin{array}{l}\text { ・連絡会等で事前に知り, 検討 } \\
\text { ・行事の予定を知る }\end{array}$ \\
\hline 治療・処置の調整 & 3 & $\begin{array}{l}\text { ·行事に合わせて治療のスケジュールを調整 } \\
\text { •つながつている点滴を一時, 止める }\end{array}$ \\
\hline 病状の連絡・調整 & 2 & $\begin{array}{l}\text { ・病状等から生徒の参加が可能であるか, 伝える } \\
\text { ・感染に注意を要する子どもの配慮について伝える }\end{array}$ \\
\hline 医療関係者の付き添い & 2 & •博物館へ行く時に医師，看護師が付き添う \\
\hline 関係者の協力 & 1 & ・ボランティア, 保護者との要項・細案打ち合わせ \\
\hline
\end{tabular}

校の体制」(4 件)、「病院の体制」(4 件) 等に関する制 限、や「児童生徒の個々の実態への配慮」(2 件) が あった。

\section{4. 博物館等施設を活用するうえでの対策}

(1) 博物館等施設を活用するうえでの対策 (Table 5 参照) : 学校が行っている対策および病院の 協力による対策については、学校による「活動内容・ 場所の工夫」（8 件）が最も多く、活動制限に関して多 くの学校が対策を行っていた。「活動内容の連絡・調
整」は、学校の依頼により 2 件、病院の協力により 3 件、「病状の連絡・調整」は病院の協力により 2 件行 われており、活動内容や病状に関して学校と病院が連 絡・調整を行っていた。また、病状・治療への対策と して、病院の協力による「治療・処置の調整」(3 件)、 「医療関係者の付き添い」(2 件) が行われていた。そ の他、学校による「病院との相互理解」(1件)、病院 の協力による「関係者の協力」(1件) が行われてお り、学校と病院が相互に理解することや、その他の関 
病院内教育における小児がんや慢性疾患の児童生徒に対する「体験的な活動を伴う学習」に関する研究

Table 6 地域の教材を活用するうえでの制限となる要因

\begin{tabular}{|c|c|c|}
\hline 類 & 件 & 体 \\
\hline 地域と結びつきが弱い & 23 & $\begin{array}{l}\text { ・地域との連絡はとっていない } \\
\text { ・通常の小・中学校と異なり, 地域との結びつきが弱い }\end{array}$ \\
\hline 児童生徒の居住地と離れている & 15 & $\begin{array}{l}\text { ・様々な地域から転入してくる児童が多い } \\
\text { ・児童生徒の居住地の教材活用が困難 } \\
\text { ・一人一人は自分の地元への思いが強い }\end{array}$ \\
\hline 病状による活動制限 & 15 & $\begin{array}{l}\text { ・病状により計画的に実施することが難しい } \\
\text { ・外出できない等の感染への配慮 } \\
\text { ・病状等のプライバシー保護ため交流が困難 }\end{array}$ \\
\hline 学校・学級の体制 & 8 & $\begin{array}{l}\text { ・ 区市町村立ではないため地域の情報を得にくい } \\
\text { ・地域の教材を活用して指導する時間の確保ができない } \\
\text { ・移動する手段の確保ができない }\end{array}$ \\
\hline 病院・病棟の体制 & 2 & •病院関係者の付き添いができない \\
\hline
\end{tabular}

Table 7 地域の教材を活用するうえでの対策

\begin{tabular}{|c|c|c|}
\hline \multicolumn{3}{|r|}{ 学校・学級による対策 } \\
\hline 類 & 件 & 具 体 \\
\hline 活動内容・方法の工夫 & 5 & $\begin{array}{l}\text { ・その日の児童生徒を考慮して活動する } \\
\text { ・できるだけ生徒のニーズに応えられる講話, 活動にする } \\
\text { ・うがい, 手洗いを徹底させる }\end{array}$ \\
\hline 活動内容の連絡・調整 & 4 & $\begin{array}{l}\text { •病院へ事前に活動内容について許可を得る } \\
\text { ・計画を早い段階で医療サイドへ提示し, 相談する }\end{array}$ \\
\hline 病院との相互理解 & 2 & $\begin{array}{l}\text { • 医師, 看護師の都合を聞き, 多忙な時はさける } \\
\text { ・学校通信で, 病院内へ活動の様子を伝える }\end{array}$ \\
\hline 病院へ付き添いの依頼 & 2 & • 医師の付き添いを依頼 \\
\hline 外部講師への配慮 & 1 & - 外部講師による風邪等の感染防止 \\
\hline \multicolumn{3}{|r|}{ 病院・病棟の協力による対策 } \\
\hline 類 & 件 & 具体 \\
\hline 学習内容への協力 & 3 & $\begin{array}{l}\text { ・医療関係者が子どものインタビュー等に答える } \\
\text { ・病院内の設備の見学では, 看護師が引率 } \\
\text { ・医師が人材の紹介 }\end{array}$ \\
\hline 病状の連絡・調整 & 3 & $\begin{array}{l}\text { •病状から生徒の参加が可能であるか知らせる } \\
\text { ・当日の体調に応じて, 授業の参加を検討し, 知らせる }\end{array}$ \\
\hline 外部講師への配慮 & 3 & $\begin{array}{l}\text { ·外部講師が病室へ入室して良いか検討 } \\
\text { ・風邪等の感染の心配のない方のみ許可 }\end{array}$ \\
\hline 病院設備の活用 & 3 & ・活動内容によりプレイルームやパントリー（食堂）等の使用を許可 \\
\hline 活動内容の連絡・調整 & 2 & $\begin{array}{l}\text { ・前もつて計画を相談する } \\
\text { ・事前に外部講師や実験等の内容を知る }\end{array}$ \\
\hline 治療・処置の調整 & 1 & ・行事に合わせて治療のスケジュールを調整 \\
\hline
\end{tabular}

係者との協力が必要であった。

5. 地域の教材を活用するうえでの制限となる要因 およびその対策

（1）地域の教材を活用するうえで制限となる要
因 (Table 6 参照)：「地域と結びつきが弱い」(23 件)、 「児童生徒の居住地と離れている」(15 件) が多く、病 院の場所が児童生徒の居住地と離孔ていることによる 制限が多かった。また、他の体験的な学習と同様に、 
Table 8 地域の教材を活用した学校・学級による実施例

\begin{tabular}{|c|c|c|}
\hline 類 & 件 & 体 \\
\hline 病院内の設備・人材の活用 & 13 & $\begin{array}{l}\text { •病院内の医師や看護師・薬剤師等を招いて話を聞く } \\
\text { •調理室や薬剤部を見学 } \\
\text { •病院関係者等身近な人のインタビュー等して, 新聞作り } \\
\text { •病院内のボランティアから音楽, 創作活動等を教わり, 心の安定が向上し, 学習 } \\
\text { 課題の発見もできた }\end{array}$ \\
\hline 近隣の図書館の利用 & 13 & •公立図書館の本等を不定期で団体貸し出しを受ける \\
\hline 地域の人材による外部講師 & 9 & $\begin{array}{l}\text { • 陶芸, 和太鼓等を指導する先生や大学の留学生を招く } \\
\text { ・地域のボランティアの方を招き, そば打ち体験 }\end{array}$ \\
\hline 地域の施設等の活用 & 4 & ・商店街・デパートへの校外学習 \\
\hline 本校等の人材・施設活用 & 4 & $\begin{array}{l}\text { ・テレビ会議システムを活用して本校の児童との交流活動 } \\
\text { •ALT との英語活動交流 }\end{array}$ \\
\hline 他の学校と交流 & 2 & $\begin{array}{l}\text { ・隣の高校生との交流学習 } \\
\text { ・他県の特別支援学校の生徒とテレビ会議を行った }\end{array}$ \\
\hline 資料を活用 & 1 & ・伝統的行事に参加は難しいが, 写真や資料により学習 \\
\hline
\end{tabular}

「病状による活動の制限」(15 件) や、「学校の体制」 (8 件)、「病院の体制」（2 件）に関する制限があった。

（2）地域の教材を活用するうえでの対策 (Table 7 参照)：学校が行っている対策および病院の協力によ る対策については、学校による「活動内容・方法の工 夫」 (5 件)、病院の協力による「学習内容への協力」 (3 件) が行われており、学習内容に関して、学校が病 院の協力を得て対策を講じていた。「活動内容の連絡・ 調整」は、学校の依頼により 4 件、病院の協力により 2 件、「病状の連絡・調整」は、病院の協力により 3 件 行われており、活動内容や病状について、学校と病院 が連絡・調整を行っていた。また、「外部講師への配 慮」が、学校により 1 件、病院の協力により 3 件行わ れ、地域の人々を外部の講師として活用していた。そ の他、病院の協力による「治療・処置の調整」(1 件)、 学校による「病院との相互理解」(2 件) も対策として 行われていた。

（3）地域の教材を活用した実施例（Table 8 参 照）：学校による「病院内の設備・人材の活用」(13 件）が最も多く、地域と結びつきが弱いことへの対策 として、多くの学校が病院内を地域ととらえて活用し ていた。また、学校による「近隣の図書館の利用」(13 件）も多く、活動制限への対策として、多くの学校が 地域の図書館から図書等の貸し出しを受けていた。そ の他、学校による「地域の人材による外部講師」(9 件) の活用も行われ、地域の人材を講師として活用し、児 童生徒が外出せずにさまざまな人々と交流する機会を 設けていた。

\section{IV. 考 察}

1. 体験的な学習を実施するうえでの制限となる要 因と学校・病院間の連携

体験的な学習の実施は、「病状による活動制限」、学 校や病院の「設備や体制の問題」「児童生徒の個々 の実態への配慮」など、種々の制限となる要因があ り、健常児と同様に行うのは難しいことが明らかに なった。

そのような制限に対して、大江・森合・志賀 (2003) は、病院内教育での実践から、医師、看護師、教員は チームであることを了解し、カンファレンスや日々の 相談を通して情報を可能な限り共有していると報告し ている。今回の調査からも、「病状による活動制限」 を補ううえで、学校から活動内容を連絡し、病院から 病状・配慮事項等の連絡を受け、調整して実施してい ることがわかつた。「設備や体制の問題」を補ううえ でも、病院の協力を得て、教材園や調理室等の「病院 内の設備」や、医療関係者や外部の人材による「外部 講師」等を活用していることがわかった。学級通信等 を利用して、「病院との相互理解」も行われていた。 体験的な学習は、学校と病院が情報を共有し、協力や 相互理解することから行えることが示唆された。

\section{2. 自然体験活動を実施するうえでの対策や具体的} 方法

横田・小野 (1995) は、経験不足に関する調査から、 慢性疾患児は動物や植物に触れる機会が少なく、健常 児より経験が多いとする項目がなかったと指摘してい る。遠藤（2006）は、特別支援学校（病弱）での実践 
から、外出して自然を観察する等の活動はできないと 報告している。今回の調査からも、自然体験活動は 「感染予防への配慮」や「病状による活動制限」の生 活規制、「飼育栽培場所の問題」「児童生徒の個々の実 態への配慮」等の制限があり、健常児と同じように行 うのは難しいことが明らかになった。

田中（2004）は、特別支援学校（病弱）での実践か ら、児童生徒は教材園で栽培を行い、経験不足に起因 する積極性や自信の欠如などを補うことができたと報 告している。今回の調査からも、回答のあった 47 校 のうち 2 割強の 11 校が、教材園を設置していた。教 材園等の活動場所は、病院の協力を得て、「駐車場の 一部に小さい栽培園を設置」「屋上ガーデンの一部を 使用」等の工夫を行い、スペースが限られている病院 の中で飼育栽培場所を確保していることがわかった。 また、33校のうち 8 割強の 27 校が、教室・校舎内や ベッドサイド等で動植物等の観察実験を行い、自然と 触れ合う活動を行っていることが明らかになった。

Table 3 に示す具体的な実践例のように、学校が感 染予防のために「ビニルパックで密封」「熱湯消毒」 等の教材や方法の工夫を行い、動植物に触れずに活動 したり、殺菌・消毒等の配慮をしたりしていることが わかった。

自然体験活動は、病院の協力を得て、活動場所・時 間、感染予防等の対策をすることで実施できることが 示唆された。

\section{3. 社会体験活動を実施するうえでの対策や具体的} 方法

今回の調査から、社会体験活動は「病状による外 出」「学校の体制」「病院の体制」「児童生徒の個々の 実態への配慮」等の制限があり、近隣施設の活用や外 部の人々との接触は、健常児と同じょうに行うのは難 しいことが明らかになった。

岩城（2004）は、特別支援学校（病弱）での実践か ら、行事や総合的な学習の時間に校外活動等の内容を 組み込むことで、児童生徒が意欲的に取り組み、充実 感をもつことができたと報告している。今回の調査か らも、回答のあった 45 校のうち 6 割弱の 25 校が校外 学習を実施しており、学校や病院の近隣施設を活用 し、社会体験活動を行っていることが明らかになった。

Table 5 に示す具体的な実践例のように、学校が活 動内容・場所を工夫することから、「学校を会場とし て出張講座を開く」「図書館から図書を長期に借用」 等を行い、病院から出ずに近隣の施設を活用している ことがわかった。また、優先されると思われる個々の
児童生徒の治療スケジュールを「行事に合わせて調 整」したり、忙しく人手の足りない状況のなか「病院 関係者の付き添い」が行われたりする等、さまざまな 病院の協力を得て実施していることがわかった。さら に、「ボランティア、保護者との打ち合わせ」等の、 病院以外からの協力を得ていることもわかった。

4. 地域の教材の活用を実施するうえでの対策や具 体的方法

文部科学省（1999）は、学校教育での教育活動の計 画や実施の場面では、家庭や地域の人々の積極的な協 力を得て、児童にとって大切な学習の場面である地域 の教育資源や学習環境をいっそう活用することが大切 であるとしている。今回の調査から、地域の教育資源 を利用するには、「地域と結びつきが弱い」「児童生徒 の居住地と離れている」「病状による活動制限」等の 制限があり、さまざまな人々との交流や近隣の施設の 活用は、健常児と同じように行うのは難しいことが明 らかになった。

遠藤（2006）は、特別支援学校（病弱）での実践か ら、児童生徒が病院の職員にかかわりをもつために、 活動場所を病院内にした実践を行い、限られた範囲の 生活によるストレスを解消し、早く退院しょうとする 前向きな態度が育ったと報告している。今回の調査か らも、病院の協力を得て、病院内を地域としてとら え、「病院内の設備・人材の活用」を行っていること がわかつた。

Table 7 およびTable 8 に示す実践例のように、病院 の協力を得て、「医療関係者が子どものインタビュー に答える」「調理室や薬剤部を見学」等を行い、病院 内の施設や人材を地域の教育資源として活用すること で、活動範囲や学習内容を広げられることが示唆され た。また、「病院内のボランティアから音楽、創作活 動等を教わり、心の安定が向上し、学習課題の発見等 もできた」との回答があり、限られた範囲での活動か らも、前向きな態度や心の安定を祆らつた活動が行わ れていた。

\section{V. まとめおよび今後の課題}

今回の調査から、入院している小児がんや慢性疾患 児を対象とした学校では、病院内にて自然や社会体験 活動を行ううえで種々の制限があることが明らかに なった。その対策として学校は、「活動内容・方法・ 場所」の工夫を行い、病院から「治療・処置の調整」 「学習内容」等の理解と協力を得ていることがわかっ た。設備や人材は病院の協力を得て、病院内を近隣の 
地域や教育資源として活用し、教育活動を展開してい ることもわかった。また、「児童生徒の病状・配慮事 項」「活動内容」の情報を病院と共有・調整し、病院 と相互に理解して活動していることが明らかになっ た。ただし、今回の調査では、社会性等に関する児童 生徒の変容や影響を把握するには至っていないため、 詳しく調査し、考察することが今後の課題となる。

ところで今回の調査では、児童生徒は自分の地元へ の思いが強いという回答がある一方、前籍校や居住地 とつながりをもたせるような実践の回答はなかった。 入院中の児童生徒が居住地や前籍校とかかわりをもつ ことにより、居住地の一員であることの自覚を促すよ うな体験的な学習の実施例について調査し、検討する ことも、今後の課題であると考えられる。

\section{文 献}

遠藤宣雄 (2006) コンピュータでプレゼンテーション 発表を活用した授業実践について一国語科の指導を 通して一. 病弱虚弱教育, 46, 84-85.

岩城三枝 (2004) 生徒一人一人を大切にした学校生活 を求めて。病弱虚弱教育, 44, 21-23.

川崎友絵・尾川端季・山崎千裕・池田友美 - 園田悦
代・郷間英世（2006）気管支喘息をもつ子どもの 「自然体験」と「生活体験」に関する実態調査. 小 児保健研究，65(1)，18-25.

川崎友絵・牛尾禮子・石田喬士 ・尾瀬 裕・郷間英世 （2008）学童期に慢性疾患に羅患した大学生の自然 体験の有用性に関する研究。小巟保健研究，67(1), 81-88,

文部科学省（1999）小学校学習指導要領解説一総則編 一.

文部科学省（2002）体験活動事例集一豊かな体験活動 の推進のために一。

文部省（1996）病弱教育の手引き一教科指導編一.

大江明子・森合道子・志賀 緑 (2003) 子どもの学 習一がん患児にとっての院内学級の意義とその活動 および課題一. 小児看護, $26,240-247$.

田中勝巳 (2004) 児童生徒の一人一人の生きる力をは ぐくむ指導のあり方一体験活動を生かした総合的な 学習の時間を通して一. 病弱虚弱教育, 44, 51-52.

横田 裕・小野純平 (1995) 一般慢性疾患児の生活経 験の不足に関する一考察. 特殊教育学研究, 32(5), $51-56$.

- 2008.3.4 受稿, 2010.10.23 受理一 


\title{
Practical Research
}

\section{In-Hospital Hands-On Learning by Children With Cancer or Other Chronic Diseases}

\author{
Tadayuki TsUCHIYA * and Tetsuro TAKEDA** \\ * Bokuto School for Special Needs Education \\ (Koutou-Ku, 135-0003) \\ ** Faculty of Education, Wakayama University \\ (Wakayama-Shi, 640-8510)
}

\begin{abstract}
Hands-on learning in everyday situations is important for the development of sociality and life skills. Elementary- and middle-school-age children with cancer or other chronic diseases need to have such learning experiences, because when they are hospitalized, their life experiences are limited. In order to clarify the current educational conditions in hospitals, teachers who had taught in hospitals answered questionnaires and were interviewed. The results revealed that some restrictions in hospitals imposed difficulties on the provision of as much hands-on experience for hospitalized children as is experienced by children who are not living in hospitals. However, the results also revealed that in-hospital education could provide hands-on experience if the content, procedure, and location of the learning activities were carefully planned in coordination with activities relating to the children's treatment, and utilizing facilities and human resources both in and outside the hospital. Further, it was suggested that hands-on learning would be possible for hospitalized children if their schools and the hospitals cooperated and shared information about the children's condition, as well as about matters needing attention and the content of the learning activities.
\end{abstract}

Key Words: hands-on learning, in-hospital education, children with cancer, children with chronic diseases 